\title{
De biomedische basisvakken zijn onverminderd van belang voor de artsopleiding ${ }^{1}$
}

\author{
W. Kuis • J.L.L. Kimpen • E.J.F.M. Custers
}

In het probleemgestuurd onderwijs worden de basisvakken niet langer op de klassieke manier, dat wil zeggen als afzonderlijke disciplines, onderwezen, maar gekoppeld aan klinische problemen. ${ }^{1}$ Vanwege het onmiskenbare succes van dit onderwijsmodel in Maastricht hebben de andere geneeskundeopleidingen onderdelen ervan overgenomen.

Zijn door deze nieuwe onderwijscurricula de biomedische basisvakken niet te veel op de achtergrond geraakt? Vaak meent men dat artsen hun biomedische basiskennis niet of zelden gebruiken. Wij denken echter dat wij die kennis meer gebruiken dan wij ons realiseren. Het is als met het spreken van een taal: men hoeft de grammaticale regels niet meer uit het hoofd te kennen om ze in de dagelijkse praktijk toe te passen. Maar men moet die regels wel één keer goed gekend hebben; daarna worden ze bijna een automatisme. In de geneeskunde ligt dat niet anders. Natuurlijk is veel klinisch werk routine geworden en geprotocolleerd, zodat de arts zich vaak niet bewust is van zijn of haar basiskennis. Uit onderzoek blijkt echter dat die kennis wel degelijk aanwezig is, maar dan in een structurerende vorm: er ontstaan "netwerken" van kennis die als het ware de structuur van onze klinische kennis vormen. Als de klinische kennis geen directe oplossing biedt voor een bepaald probleem, kan men op deze netwerken terugvallen. ${ }^{2-3}$ Zonder die basiskennis gaat het goed tot een ziektegeschiedenis zich anders presenteert of gedraagt. Een goed begrip van ziekten en het beloop en

W. Kuis $(\bowtie)$

Prof. dr. W. Kuis is kinderarts-immunoloog in het Wilhelmina

Kinderziekenhuis.Correspondentieadres:Prof. dr. W. Kuis,

Universitair Medisch CentrumUtrecht, Locatie Wilhelmina

Kinderziekenhuis, Postbus85.090, 3508 AB Utrecht, w.

kuis@umcutrecht.nl.Belangenconflict: geen gemeld.Financiële

ondersteuning: geen gemeld. de respons op een behandeling berust vaak op kennis en begrip van de pathofysiologie. Daarvoor zijn de biomedische basisvakken onontbeerlijk. Met het aanleren van "klinische beelden" alleen bestaat het risico dat men bijzondere of zeldzame klinische manifestaties niet herkent doordat men niet begrijpt waardoor het soms anders kan lopen. Studenten die de biomedische verklaring van een diagnose moesten leren, bleken een week later een aantal casussen beter te diagnosticeren dan studenten die alleen leerden dat bepaalde symptomen statistisch gekoppeld waren aan een bepaalde diagnose. ${ }^{4}$ Ook voor het begrijpen van de werkingen en bijwerkingen van medicijnen en om beargumenteerd weerwoord te kunnen bieden aan claims van artsenbezoekers en van de farmaceutische industrie is kennis van de basisvakken, waaronder de farmacologie, onontbeerlijk.

Daarom moeten de basisvakken in het huidige curriculum versterkt worden. Wij zien de huidige arts niet als een professional die alleen gedrild is in het herkennen van klinische beelden en het toepassen van evidence based medicine. Hij of zij moet ook begrijpen dat een ziekte zich anders kan manifesteren, waardoor een behandeling niet of averechts werkt. Bij klinische situaties die men nog niet eerder heeft meegemaakt, komt het erop aan met biomedische basiskennis de klinische verschijningsvormen terug te brengen in een referentieschema. Bij zo'n arts kan de patiënt zich in goede handen voelen.

\section{Summary}

The contemporary physician is not merely a professional who is trained in the recognition of clinical syndromes and the application of evidence-based medicine. A good understanding of the basic biomedical sciences is necessary to comprehend what is wrong with a patient and what form of treatment is the most appropriate,

\footnotetext{
${ }^{1}$ Dit artikel verschijnt ook in het Nederlands Tijdschrift voor Geneeskunde.
} 
especially if a disease manifests itself in an unfamiliar way. (Kuis W, Kimpen JLL, Custers EJFM. The basic biomedical subjects are of undiminished importance for the training of medical doctors. Dutch Journal of Medical Education 2007;26(2):93-94.)

\section{Literatuur}

Neufeld VR, Barrows HS. The "McMaster Philosophy": an approach to medical education. J Med Educ 1974;49:1040-50.
Boshuizen HPA, Schmidt HG. On the role of biomedical knowledge in clinical reasoning by experts, intermediates and novices. Cognitive Science 1992;16:153-84.

Rikers RMJP, Schmidt HG, Moulaert V. Biomedical knowledge: encapsulated or two worlds apart? Applied Cognitive Psychology 2005;19:223-31.

Woods NN, Brooks LR, Norman GR. The value of basic science in clinical diagnosis: creating coherence among signs and symptoms. Med Educ 2005;39:107-12. 